\title{
TOURISM IMAGINARIES: A CONCEPTUAL APPROACH
}

\author{
Noel B. Salazar \\ University of Leuven, Belgium
}

\begin{abstract}
It is hard to imagine tourism without the creative use of seductive as well as restrictive imaginaries about peoples and places. This article presents a conceptual framework for the study of tourism imaginaries and their diffusion. Where do such imaginaries originate, how and why are they circulated across the globe, and what kind of impact do they have on people's lives? I discuss the multiple links between tourism and imagination, illustrating the overlapping but conflicting ways in which imaginings and fantasies drive tourists and tourism service providers alike. By applying this conceptual approach to international tourism in developing countries, I illustrate how the critical analysis of imaginaries offers a powerful deconstruction device of ideological, political, and sociocultural stereotypes and clichés. Keywords: imaginary, imagination, fantasy, tourism mobility, circulation of ideas, transdisciplinary theory. (C) 2011 Elsevier Ltd. All rights reserved.
\end{abstract}

\section{INTRODUCTION}

"He that travels in theory has no inconveniences; he has shade and sunshine at his disposal, and wherever he alights finds tables of plenty and looks of gaiety. These ideas are indulged till the day of departure arrives, the chaise is called, and the progress of happiness begins. A few miles teach him the fallacies of imagination. The road is dusty, the air is sultry, the horses are sluggish, and the postilion brutal. He longs for the time of dinner that he may eat and rest. The inn is crowded, his orders are neglected, and nothing remains but that he devour in haste what the cook has spoiled, and drive on in quest of better entertainment. He finds at night a more commodious house, but the best is always worse than he expected."

Samuel Johnson (1963 [1759], p. 181; emphasis added)

The historical quote above includes a critical reflection on the imaginative qualities of a "dream holiday". As with many other activitiesreading novels, playing games, watching movies, telling stories, day-

Noel B. Salazar is Research Fellow of the Research Foundation Flanders at the University of Leuven (Cultural Mobilities Research, Parkstraat 45, bus 3615, BE-3000 Leuven, Belgium. Email <noel.salazar@soc.kuleuven.be>). His research interests include anthropologies of mobility and travel, the local-global nexus, discourses and imaginaries of Otherness, heritage interpretation, culture contacts and cosmopolitanism. He is the author of Envisioning Eden: Mobilizing Imaginaries in Tourism and Beyond (Oxford: Berghahn, 2010). 
dreaming, et cetera-planning a vacation and going on holidays involve the human capacity to imagine or to enter into the imaginings of others. Some even argue that "to remake the world imaginatively" is “our most specifically human mission”' (Brann, 1991, p. 774). The vernacular imaginings people rely on, from the most spectacular fantasies to the most mundane reveries, are usually not expressed in theoretical terms but in images and discourses. Imaginaries exist "by virtue of representation or implicit understandings, even when they acquire immense institutional force; and they are the means by which individuals understand their identities and their place in the world" (Gaonkar, 2002, p. 4). Shared imaginaries can be "'about other people, as with the nineteenth- and early twentieth-century European imagining of African peoples as cannibals. They can be about other places, as with the British colonial idea of 'the tropics' as steaming hot year round, disease ridden, and somewhat dangerous"' (J. Adams, 2004, p. 295).

Scholars from a wide array of disciplines have given attention to the imagination (Brann, 1991; Kearney, 1998; Strauss, 2006). The imaginary has been conceptualized, for instance, as a culture's ethos or a society's shared, unifying core conceptions (Castoriadis, 1987), a fantasy or illusion created in response to a psychological need (Lacan, 1977) and a cultural model or widely shared implicit cognitive schema (Anderson, 1991; Taylor, 2004). Most conceptualizations have been developed in the fields of continental philosophy (the phenomenological and hermeneutic legacies of Merleau-Ponty, Husserl, and Heidegger), psychoanalysis (including archetypal and transpersonal psychology), poststructuralism (especially Deleuze), the social sciences (Latour and the literature on enchantment), visual studies (Mitchell), analytical philosophy (the philosophy of mind and of aesthetics), and, increasingly, the intersection of these various approaches and the neurosciences (Roth, 2007). I conceptualize imaginaries as socially transmitted representational assemblages that interact with people's personal imaginings and are used as meaning-making and world-shaping devices. The imaginary is both a function of producing meanings and the product of this function (Ricoeur, 1994). Many imaginaries are structured by dichotomies, sometimes difficult to discern in practice, that represent the world in paradigmatically linked binominals: nature-culture, here-there, male-female, inside-outside, and local-global (cf. Barthes, 1972 and his concept of "mythologies"; Durand, 1999).

Imaginaries are "complex systems of presumption-patterns of forgetfulness and attentiveness - that enter subjective experience as the expectation that things will make sense generally (i.e., in terms not wholly idiosyncratic)" (Vogler, 2002, p. 625). Although culturally shaped imaginaries influence collective behavior, they are not necessarily an acknowledged part of public discourse or coterminous with implicit or covert culture. They are unspoken schemas of interpretation, rather than explicit ideologies, building "upon implicit understandings that underlie and make possible common practices" (Gaonkar, 2002, p. 4). While imaginaries are alienating when they take on an institutional(ized) life of their own (e.g. in religion or politics), 
in the end the agents who imagine are individuals, not societies. An individual's propensity to produce imaginings is the primary fact; economy and politics provide triggering mechanisms (e.g. d'Hauteserre, 2011), assisting in bringing idiosyncratic images together in socially acceptable formulas, but remaining secondary facts when studying the sociocultural production of imaginaries.

It is hard to think of tourism without imaginaries or 'fantasies'- the original Greek word for imagination, often used nowadays to denote more playful imaginaries related to things that are improbable or impossible (cf. Reijnders, 2011). This article presents a conceptual framework for the study of tourism imaginaries and their transmission. I discuss the multiple links between tourism and imagination, illustrating the overlapping but conflicting ways in which imaginings drive tourists and tourism service providers alike. I pay particular attention to how personal imaginings interact with and are influenced by institutionally grounded imaginaries implying power, hierarchy, and hegemony. Although the processes are similar, I do not deal here with the industrial "imagineering" of new environments for tourism and leisure (e.g. Imagineers, 1996). Instead, I focus on how otherwise lived spaces are shaped by and are shaping tourism practices and fantasies. Where do tourism imaginaries come from, how and why are they circulated across the globe, and what material impact do they have on people's lives? By applying the developed conceptual framework to international tourism in developing countries, I illustrate how the critical analysis of tourism imaginaries offers a powerful deconstruction device of ideological, political, and socio-cultural stereotypes and clichés.

\section{THE (IM)MOBILITY OF TOURISM IMAGINARIES}

As Franklin reminds us, "it was not difference and the extraordinary that created tourism but the opposite, the extension of belonging, the prospect of taking up a place in the new national cultures that beckoned them" (Franklin, 2004, p. 298). However, as modern tourism in its various forms historically expanded across nation-state borders and continents, international tourism quickly became "the quintessential business of 'difference projection' and the interpretive vehicle of 'othering' par excellence"' (Hollinshead, 1998b, p. 121). In a global market characterized by rapidly changing trends, the products and packages on sale vary widely, but the image-making machinery behind them shares well-established strategies and scripts. Seductive images and discourses about peoples and places are so predominant that without them there probably would be little tourism, if any at all (Bishop \& Robinson, 1999).

Stories, images, and desires, running the gamut from essentialized, mythologized, and exoticized imaginaries of otherness to more realistic frames of reference often function as the motor setting the tourism machinery in motion (Amirou, 1995). Marketers eagerly rely on them to represent and sell dreams of the world's limitless destinations, activ- 
ities, types of accommodation, and peoples to discover and experience. Prospective tourists are invited to imagine themselves in a paradisiacal environment, a vanished Eden, where the local landscape and population are to be consumed through observation, embodied sensation, and imagination. If anything, tourism is part of the "image production industry" (Harvey, 1989, pp. 290-293), in which identities of destinations and their inhabitants are endlessly (re)invented, (re)produced, (re)captured and (re)created in a bid to obtain a piece of the lucrative tourism pie (cf. Kirshenblatt-Gimblett's (1998) ontological 'hereness' and 'madeness' of places, peoples, and pasts). This is especially true of cultural tourism or tourism with cultural elements (Amirou, 2000).

\section{Study Methods}

Studying imaginaries seems as daunting as it is exciting. According to Kant, the imagination is "a hidden art in the depths of the soul whose true devices nature will scarcely let us divine and spread exposed before our eyes" (cited in Brann, 1991, p. 32). By their very nature, imaginaries remain intangible, so the only way to study them is by focusing on the multiple conduits through which they pass and become visible in the form of images and discourses. These channels include the visual and textual content of documentaries and fiction movies; art, museum exhibitions, and fairs; trade cards, video games, and animation; photographs, slides, video, and postcards; travelogues, blogs, and other websites; guidebooks and tourism brochures; literature, coffee-table books, and magazines; news coverage and advertising; official documents; and quasi-scientific media such as National Geographic.

Once imaginaries are recognized and identified, they can be operationalized as real (networks of) social practices. Through a combination of historical and ethnographic methods, it is possible to assess how imaginary activities, subjects, social relations, et cetera are materialized, enacted, and inculcated. Thus, although the precise workings of imaginaries are hidden from view, the operating logic can be inferred from its visible manifestations and from what people say and do. Tourism imaginaries in particular become tangible when they are incarnated in institutions, from archaeological sites, museums, and monuments to hotels, media, and cultural productions (Wynn, 2007, p. 21). Careful empirical study of situated articulations and (dis)connections between tourism imaginaries and their broader context is a fruitful way of analyzing tourism. As this article is conceptual rather than empirical, the ethnographic illustrations below remain brief. Detailed examples of the principles described here can be found elsewhere (Salazar, 2005; Salazar, 2006; Salazar, 2009; Salazar, 2010).

In order to understand how tourism's foundational imaginaries circulate and perpetuate themselves, we need theoretical frameworks that allow a comprehensive study of inner dynamics that transcend the unproductive binary opposition between the economic global and the cultural local. One such holistic conceptualization is the "circuit 
of culture" model, which encompasses the circulating production, consumption, regulation, representation, and identity of culture ( $\mathrm{Du}$ Gay, Hall, Janes, Mackay, \& Negus, 1997). The circuit metaphor depicts cultural processes as complex and interdependent sets of distinct but not discrete moments. This helps us grasp how culture deploys power to shape identities and subjectivities within a circuit of practices that range from the production and distribution of goods and representation to an ever-growing emphasis on regulation and consumption. The study of individual moments at which meaning is constructed only gives us a partial view of how the meanings associated with a particular imaginary are produced, negotiated, and contested. As such, the circuit of culture model moves away from one-way processes towards viewing globally circulating products and processes such as imaginaries, in a more integrated way, as circulation and dissemination.

According to Ateljevic, circuits of tourism are "a dynamic interconnected whole, where players and stakeholders may (re)align themselves with any other player or stakeholder as need, desire or opportunity allows" (Ateljevic, 2000, p. 382). Several scholars have applied the circuit of culture concept to tourism (e.g. Bruner, 2005; Dann, 1996, pp. 136-169; Jenkins, 2003; Said, 1994, pp. 92-95). A related theoretical approach that equally stresses the dialectics of production and consumption uses the metaphor of performance-tourism as a mutually negotiated relationship between consumers and producers, simultaneously a cultural product and producer of culture. This kind of theorizing is an attempt to move beyond the passive gaze of the visual and to explore the embodiment of the acts of production and consumption (Bærenholdt, Haldrup, Larsen, \& Urry, 2004; Coleman \& Crang, 2002). Such approaches allow us to study not only how the existing power relations and inequalities that characterize circulating tourism imaginaries are maintained, reproduced and reinforced, but also how they are challenged, contested, and transformed (Edensor, 2001).

While there is ample scholarship on the production and consumption of tourism discourses and images, much less attention has been given to their actual distribution within the circuit of tourism. Studying the circulation of imaginaries reveals how cultural representations are mixed together, consumed, and interpreted. In his study on contemporary media productions of Tibet, Mercille (2005), for instance, shows the remarkable homogeneity of Shangri-La imaginaries in a movie (Seven Years in Tibet), a guidebook (Lonely Planet), and a magazine (National Geographic). One master image of Tibet seems to circulate by the various representations of it. In a similar vein, Bruner (2005) talks about tourism imaginaries in terms of "metanarratives" (cf. White's (1978) "tropics of discourse"), and calls them "the largest conceptual frame within which tourism operates. They are not attached to any locality or to any particular tour, and they are usually taken for granted, not brought to consciousness" (Bruner, 2005, p. 21).

An increasingly popular way used to study issues of circulation is actor-network theory, developed in science and technology studies (Latour, 2005; Law \& Hassard, 1999). It conceptualizes all actors 
involved in a network (both human and non-human) as part of a wellconnected global entity that remains nevertheless continuously local. Actor-network theory provides a means of understanding how everyday practices are transmitted into wider processes of social transformation, but without falling back on an all-encompassing theoretical order. Importantly, this approach emphasizes processes of translation, the methods by which actors form associations with other actors by which actor-networks are established and stabilized. This transformative character is crucial in that in networks-consisting of social relations, material (infra)structures, and virtual relations-every single actor can potentially make use of a series of translating, modifying, or distorting processes (van der Duim, Jóhannesson, \& Ren, in press). While actornetwork theory certainly offers innovative ways of tracing and describing the global circulation of imaginaries, its explanatory force is rather weak. It only helps us understand in what directions images and ideas move, and how they circulate and are transformed (translated) during circulation, but not necessarily why this is the case.

Anthropology may give us some important clues here (Salazar, 2010; Skinner \& Theodossopoulos, 2011). In his analysis of the cross-generational circulation of myths, Urban notes that "whatever is in motion tends to remain in motion unless something else stops it" (2001, p. 15). Not surprisingly, some scholars have pointed to the similarity between myths-traditional explanatory stories (often of a sacred nature)—and tourism imaginaries (Hennig, 2002; Selwyn, 1996). Tourism images and ideas easily travel, together with tourists, from tourism-generating regions (which are also destinations) to tourismdestination regions (which also generate fantasies) and back. However, tourism imaginaries do not float around spontaneously and independently; rather, they "travel" in space and time through well-established conduits, leaving certain elements behind and picking up new ones along the way, and continuously returning to their points of origin. Such circulation always "takes time-historical time-and is not instantaneously achieved" (Urban, 2001, p. 105).

How exactly imaginaries influence a broad public is an ambiguous question that merits grounded ethnographic research on reception and consumption rather than mere ideological critique. Images, discourses, and ideas have certain points of origin-in tourism many of them are marked by distinctly Western genealogies-but are now incessantly moving in global "rounds", not strictly circular, reaching new horizons and periodically feeding back to their places of departure. As with myths, the older the imaginaries and the longer they have been circulating, the harder it becomes to trace where they originated. Imaginaries circulate unevenly, not freely; their spread is shaped by processes that delimit and restrict movement. In its articulation between the ideological and the material, the circulation of imaginaries requires some sort of material and institutional infrastructure of movement. In order to understand how circulation works, we not only need to study what is circulating but also the socio-cultural structures and mechanisms that make that circulation possible or impossible. 
Empowered by imagined vistas of mass-mediated master narratives, tourism imaginaries have become global (Crouch, Jackson, \& Thompson, 2005). They are now sent, circulated, transferred, received, accumulated, converted, and stored around the world. The circulation of images and narratives of otherness signify familiar notions of global difference. Through this continuous circulation, which is "a constitutive activity of representations" (Crang, 2006, p. 48), tourism fantasies help in (re)creating peoples and places. In the words of Hollinshead, "This immense imaginary power to invent iconic traditions afresh or to manufacture felt authenticities amounts to the 'fantasmatics' of global tourism image-making, rhetoric mongering, and discourse articulations, viz. the very craft by which not only knowledge but life-style and life-space is created.' (Hollinshead, 1998a, p. 75). Global tourism disembeds images and ideas of peoples and places from their original context, making them available through their transformation, legitimization, institutionalization, and distribution.

Tourism imaginaries are easily re-embedded in new contexts by a process that constantly alters both the imaginaries and the contexts, building on local referents to establish their meaning and value. It is no coincidence that 'travel' is linguistically related to the French word travail, which means labor. Tourism involves networked orderings of people, natures, materials, mobilities and cultures; production as well as consumption of those different elements (van der Duim, et al., In Press). As actor-network theory stresses, everything circulating within such networks is continuously "translated", deformed and modified (Latour, 2005). In some destinations, tourism imaginaries are so firmly established and all-encompassing that they are difficult to escape. In other places, the images and ideas are much more diffuse and open to changes (Bruner, 2005; Picard, 1996). Indeed, reproduction processes are rarely without negotiation and resignification; more often, they are cases of (re)entextualization rather than mere replication. The circulation of tourism discourses and imaginaries is, in many respects, a translocally negotiated process involving variously situated actors and their glocal engagements with tourism to (re)produce "stereotypic images, discredited histories, and romantic fantasies" (Bruner, 2005, p. 76). Rather than mere projections, these transactions are negotiated in various ways and both restrict the lives of people and create new subject positions.

Analyzing the global circulation of images and ideas of tourism-a constant interaction between documents, devices, and people-and seeking to determine the local dynamics of this exchange is a complicated matter. Imaginaries often become the symbolic objects of a significant contest over economic supremacy, territorial ownership, and identity. In the eyes of Western tourists, for example, Africa is often seen as dangerous and to be avoided, while Asia is constructed as simultaneously risky but also exotic and worth experiencing (Carter, 1998). One can even go more detailed: tourism imaginaries about the Pacific distinguish a masculinized Melanesia from a feminized Polynesia (Stephen, 1999). This does not mean that such imaginaries enter into public circulation with their meanings already defined according to some 
pre-existing cultural matrix; nor are they innocent of history. As new forms of circulation come to shape our world to an unprecedented degree, understanding the historical specificities of these global processes is a central challenge for scholars. This will become clear in the ethnographic examples below.

\section{Imag(in)ing Otherness}

Alain and Bernadette are a young French couple on their honeymoon in Indonesia. After having spent a relaxing week on the island of Bali, they visit Yogyakarta, the cultural heartland of Java. First on their to-see list are the world heritage sites of Prambanan and Borobudur. On their last day, they decide to hang around town and visit the Sultan's Palace and the adjacent Water Castle. Tamansari, as it is locally known, was the former pleasure garden of the Sultan, a complex of enchanting pavilions and mesmerizing swimming pools. Julius, one of the on-site guides, shows the newlyweds around. Enthusiastically enacting the role of the Sultan, he takes Bernadette firmly by the arm while strolling from the women's swimming pool to the Sultan's private pool and adjacent quarters. Julius convincingly tells the tourists how life was organized back in the days: "The Sultan chose one woman a day, not two. That was enough. . The seventh Sultan was the most roguish; he had six wives. Why was he roguish? He had only six wives. That is to say, during every given week he still had one day to rest ... to watch the football game on Sundays!" At the castle's watchtower, Julius specifically invites Alain to go upstairs "to watch and take pictures". Once at the upper level, observing the make-believe harem girls around the pool, Julius continues: "Ah, woman [number] 26, come! ... And on other days he [the Sultan] chooses other women: number 12, 3,... The women were wearing a sarong, no bikini, ya, a long sarong."

The pools of the Water Castle in Yogyakarta are still there but the lovely girls bathing have long disappeared. Yet tourists are invited to participate in a performance that will bring an imagined past back to life, namely that of the oriental harem. This Islamic institution (etymologically linked to the Arabic haram, 'something prohibited') exerted a certain fascination on the European imagination, especially during the Romantic Period (due in part to Richard Francis Burton's translation of One Thousand and One Nights, which included extensive footnotes on oriental sexual practices). Many people imagined a harem as a brothel with sensual wives and concubines (including abducted European girls) lying around pools with naked oiled bodies, with the sole purpose of pleasing the powerful man to whom they had given themselves. Although historically incorrect (Lewis, 2004), much of this imaginary continues circulating through orientalist art and its reproduction and clichés (Beaulieu \& Roberts, 2002), including in movies (Bernstein \& Studlar, 1997).

Making multiple (often playful) references to this harem imaginary, the Water Castle is depicted as a Garden of Eden with guiltless sexuality and freedom from work and want, and the physical structure perfectly lends itself for guides to enact such fantasies (imagination at play). 
After the tour described above, Alain commented upon Julius: "He's full of nostalgia... Before it was better." One could, indeed, see the eroticized representations of this heritage site as a form of nostalgia, a kind of mourning for the destruction of an imagined traditional culture (or a sexualized and eroticized one). Yet this is not just a sentiment, it is a script, performed and enacted on site. Modern myths-nature, the noble savage, art, individual freedom and selfrealization, equality, and paradise-all have special significance for and are manifested in the social practices of international tourism (Hennig, 2002). Various imaginaries combine to offer a program of travels through fantasy space that legitimizes some of the daydreams of traveling individuals. Dann (1976) distinguishes two basic characteristics underlying all tourist fantasies. On the one hand, there is the overcoming of monotony, anomie and meaninglessness of everyday life with more satisfying experiences-escapism and the desire for exoticism or difference. On the other hand, there is the boosting of personality-ego-enhancement, leading to the accumulation of symbolic capital. Such desires, however, are not simply internalized wishes but, rather, part of widely shared imaginaries that are articulated through constellations of social practice and media (Crouch, et al., 2005).

Echtner and Prasad (2003) identify three recurring myths in tourism to developing countries: the myth of the unchanged, the myth of the unrestrained and the myth of the uncivilized. As Brann reminds us, such myths are "systemic public illusions, spontaneous or manipulated by the image-makers" (1991, p. 546). Destination marketers, however, have no monopoly over manufacturing the exotic. Tourism fantasies are always situated within wider socio-cultural frameworks (Hutnyk, 1996). They emerge not from the realm of concrete everyday experience but in the circulation of more collectively held images. Tourism imaginaries of peoples and places cannot be considered simply as commoditized or commercial representations with an interpretative or symbolic content. As the ethnographic vignette above illustrates, they often propagate historically inherited stereotypes that are based on the (colonial) myths and fantasies that form part of an imaginary.

Discourses of the past-orientalism, colonialism and imperialismseem to be fertile ground for nostalgic and romantic tourism dreams (Edensor, 1998; Henderson \& Weisgrau, 2007). The imagery used in tourism to developing countries is about fantasies, and often about an ambivalent nostalgia for the past-ambivalent because returning to the past is not what people actually desire (Bissell, 2005). Appadurai (1996, pp. 76-78) calls such nostalgia without lived experience or collective historical memory, "armchair nostalgia" or "imagined nostalgia”. The ambivalence is also captured in Rosaldo's (1993, pp. 69-70) notion of "imperialist nostalgia", "a particular kind of nostalgia, often found under imperialism, where people mourn the passing of what they themselves have transformed". This would apply particularly well to the imaginaries of the oriental harem. In any of its versions, “imperialist nostalgia uses a pose of 'innocent yearning' both to capture people's imaginations and to conceal its complicity with often brutal domination'. The acceleration of the transnational circulation 
of images and signs, contact with other cultures, and the expansion of tourism industries have facilitated "the global institutionalization of the nostalgic attitude" (Robertson, 1990, p. 158).

Critical scholarship reveals how broader cultural and ideological structures create and mediate tourism representations (Ateljevic, Pritchard, \& Morgan, 2007; Hall \& Tucker, 2004; Morgan \& Pritchard, 1998; Mowforth \& Munt, 2008; Selwyn, 1996; Urry \& Larsen, 2011). Images of difference have been (re)constructed over centuries of cross-cultural contact. In the case of Western tourism to developing countries, the circulating representations cater to certain images within Western consciousness about how the Other is imagined to be. Such imaginaries form a "representational loop" (Sturma, 2002, p. 137) that heavily relies upon the fictional worlds of literature, film and the fine arts to give "authenticity" to peoples and places (Hennig, 2002; Robinson \& Andersen, 2002; Urbain, 1994). At the same time, tourism imaginaries do not exist in a vacuum, but have to contend with other circulating images and ideas. Global media streams overwhelm people with thousands of impressions of the world, in real time. In the case of developing countries, the competing imagery is often negative and the media can be very selective in what they show or do not show their audiences.

Not surprisingly, the currently dominant tourism discourses draw upon and extend mythologized (colonial) visions of Otherness from popular culture, (travel) literature and academic writings in disciplines such as anthropology, archaeology and history (Clifford, 1997; Pratt, 2008; Said, 1994; Torgovnick, 1990). The discourses surrounding ecotourism, for example, are closely related to the much wider global ecological imaginary of late twentieth-century environmentalism, while nostalgia tourism often taps into commoditized (neo)colonial imaginaries and evokes and mimics the trope of "first contact" that was common in colonial travel narratives (Pratt, 2008). Henderson and Weisgrau, for instance, note how guidebooks about India remarkably mirror the accounts of nineteenth century British colonial tourists, with a recycling of the mythic foci grounded in these earlier accounts which evoke an Orientalist imaginary of India, "replete with moral judgments about the superiority of western 'civilization', mixed with the desires evident in fantasies about romance, decadence, sensuality, cruelty, sex and the unfathomable" (2007, p. xvii). Of course, we should acknowledge that there were many different imaginaries being played out in the colonial era too.

For Said (1994), geographic imaginaries refer, literally, to how spaces are imagined, how meanings are ascribed to physical spaces (such that they are perceived, represented and interpreted in particular ways), how knowledge about these places is produced, and how these representations make various courses of action possible. Tourist ways of "seeing" places often differ from other representations because places are being fashioned in the image of tourism (Hughes, 1992). The Caribbean as "tropical nature", for example, is mobilized through a range of tourism imaginaries and practices (Sheller, 2004, p. 17). The past is being reworked by naming, designating, and historiciz- 
ing landscapes to enhance their tourism appeal (Bacchilega, 2007; Gold \& Gold, 1995). Who represents what, whom and how are critical and often contested issues for socio-cultural insiders as well as outsiders (K. M. Adams, 2004; Morgan \& Pritchard, 1998; Mowforth \& Munt, 2008). There are important bonds between imaginative geographies and imagined communities as peoples and places are constructed in both the imaginative and the material sense (Anderson, 1991; Gregory, 1994).

\section{Imaginaries of (Im)mobility}

Koinet is a young Maasai who grew up in the hills of Monduli. After finishing secondary school in Arusha he decides to leave the cattle trade to his brothers and to try his luck in the thriving tourism business of northern Tanzania. With a certificate from the Arusha Guide School he finds a part-time job as a cultural tourism guide. On the day I meet him, Koinet is guiding a group of American tourists on a daytrip to villages around Tanzania's safari capital. On the way to a local market, he briefs the group: "We will be able to meet the local people at the market place. You can say habari, so you can become popular suddenly, and they can respect you because you greet them in their language". In the afternoon, the group visits a Maasai homestead and Koinet tells the tourists: "This Maasai family has only fifteen children! [everybody laughing]". Explaining the traditional use of local flora: "This leaf, croton leave, is edible. Old people use it like toilet paper, very smooth!". While watching the Maasai warriors sing and dance, he comments: "I don't know how they do it". One of the tourists remarks that the singing men look like they are taking a course on how to become Tom Waits. Koinet does not know how to react, because he has never heard of the American singer-songwriter. Before leaving the hamlet, the tourists are invited to put on Maasai clothes for a nice photo shoot.

The Maasai are a widely dispersed group of semi-nomadic pastoralists and small-scale subsistence agriculturists who occupy arid and semi-arid rangelands in southern Kenya and northern Tanzania. The relationship between tourism and Maasai has been largely determined by safari imaginaries (Salazar, 2009). Due to countless coffee-table books, movies, and snapshots, everybody seems to "know" the Maasai, a fact some business-minded Maasai themselves exploit. The sight of a virile Maasai warrior, dressed in colorful red blankets and beaded jewelry, evokes the romantic image of a modern "noble savage". Koinet, however, performatively resists stereotyping by not stressing the fact that he himself is a Maasai or that he, as a local, often frequents the visited market to buy his groceries and second-hand clothes. As a tour guide, he talks about the Maasai in a way that distances himself from the "uncivilized" practices he is narrating. Moreover, his guiding discourse and practice is full of implicit references to his personal wish to climb socially.

The turning into tourism products and packages of the everyday, the alternative, the intangible, and that which has not yet been memorialized in guidebooks and official histories is a response to the increasing 
demand for experiential tourism, often based on processes of temporal and spatial Othering (cf. Fabian, 2002). This offers the opportunity to move from (more passively) lived imagining, which is self-enclosed and concentrated on the imaginaries themselves, to (more actively) experienced imagining, which is directed and intentional (Kunz, 1946). A visit to a Maasai settlement, for instance, is told and sold (often by the Maasai themselves) as an exotic journey to the past. Interestingly, contemporary life is represented as time-frozen and pre-modern. Maasai are presented and represent themselves as unique, separate, and fixed.

Even though some scholars hint at the mobility of people living and working in tourism destinations, others seem to silently reinforce the false binary between mobile tourists and place-bound locals, echoing the earlier dichotomy in anthropology, whereby "'Natives' are incarcerated in bounded geographical spaces, immobile and untouched yet paradoxically available to the mobile outsider" (Narayan, 1993, p. 676). Locals, in this conceptualization, have a strong local identity and local "roots". Their cultural capital is tied to local culture(s), whereas cosmopolitans possess "cosmopolitan capital"-resources, knowledge, and abilities that facilitate social as well as geographical mobility (Salazar, 2010). Tourism marketers borrow from traditional ethnology an ontological and essentialist vision of exotic cultures, conceived as static entities with clearly defined characteristics (Thomas, 1994). Ideas of old-style colonial anthropology_objectifying, reifying, homogenizing, and naturalizing peoples-are widely used by a variety of tourism shareholders, staking claims of identity and cultural belonging on strong notions of place and locality (read: immobility).

Tourism imaginaries are always the co-product of local people, mediators and tourists, and these different stakeholder groups are simultaneously intermediaries and consumers. Local tourism service providers such as Koinet are positioned in the liminal space between mobile tourists and locals, who are represented and imagined as being immobile. The qualifier "local" does not necessarily imply that these people are natives of the place where they operate, although they are habitually perceived as such by foreign tourists. The more people are seen as immobile-true "natives" (living in the place where they were born) - the more they must be authentic, so the stereotypical tourism thinking goes. Local tourism workers are also liminally positioned in a temporal sense, both representing the past (for tourists) and dreaming of the future (for themselves). The ethnographic vignette above nicely illustrates these processes.

Knowing perfectly well that in many developing countries the locals, as much as the sights seen, are part of the attraction, tourism workers are projecting themselves into immobile (and, by association, more authentically local) roles. This makes people such as Koinet complicit in the perpetuation of biased global tourism imaginaries of time-frozen social identities and cultural traditions. Thus, many experiential tours in the countryside are not about how life is currently being lived. Rather, they give tourists a mythologized, nostalgic version of premodern rural life (often exactly what tourists expect). Tourism workers facilitate the tourist experience-which includes not only seeing, but 
also doing and feeling things-by themselves blending in with the tourism imaginaries that are being enacted. This includes changes in how they dress, how they behave, and how they talk. Indeed, guides such as Koinet will often dress in the typical Maasai gear and will seldom mention their own travel experiences abroad, because travel both inscribes and erases the difference between powerful outsiders and vulnerable local people.

There is more at play in tourism, however, than a mere replication of global tourism imaginaries of local immobility. While on the discursive level, tourism service providers are (re)producing globally dominant images and ideas, on the metadiscursive level they seem to be conveying a surprisingly dissonant message (Salazar, 2010). There are many instances where shifts of role alignment occur and the common asymmetry between immobile locals and mobile tourists is blurred or temporarily interrupted. Two different logics are at work simultaneously: a provincial logic of differentiation that creates differences and divisions, and a cosmopolitan logic of equivalence that subverts existing differences and divisions. In some instances, tourism workers find creative ways to distance themselves from local people and align themselves on the side of the tourists (see the ethnographic vignette above). They prefer to position themselves as different from the represented locals and more similar to their foreign clients in a bid to enhance their own cosmopolitan status and to gain symbolic capital, using their privileged contact with foreigners to nourish their utopias of escape from the harsh local life.

The tourism encounter is the setting where not only much cosmopolitan capital is accrued but also tacitly used to better serve foreign tourists. Cosmopolitan tourism workers often use transcultural frames of reference to translate the perceived strangeness of their own culture into an idiom familiar to the tourists, finding connections between what is being experienced and what tourists already know. However, this display of transcultural knowledge often stays at the metadiscursive level. This is to avoid tensions because tourists exactly expect tourism workers to be local experts, granting them their authenticity based on their expressions of nativeness. The explicit display of their cosmopolitan aspirations and lifestyle thus needs to happen elsewhere. They can brag to their relatives, friends, and colleagues about how much they are up-to-date with trends in global popular culture and modern technology. Bringing too much of this into the encounter with foreign tourists, however, would disrupt the magic of tourism.

No matter how hard they try to be cosmopolitan, giving evidence of their cultural mobility on an imaginative level, tourists continue seeing tourism workers as "local", in part because tourism imaginaries create a kind of economically driven denial of mobility (similar to Fabian's (2002) "denial of coevalness"). A similar analysis has also been made regarding photography. Still photographs stand diametrically opposed to the natural flow of life. The photograph is a silent, immobile rigor mortis of reality, a symbolic death (Barthes, 1972). This temporal ambiguity is of major significance for a great deal of tourist activity is directed at experiencing the past (Lowenthal, 1985). The more mobile 
tourism service providers are-having travelled physically or in their imagination - the better they are at representing and framing the globalized lifeworld around them and themselves as distinctively local.

Paradoxically, their dreams of moving (geographically) forward and (socially) upward-becoming more cosmopolitan (and more modern) - can only materialize if they represent to tourists the lifeworld in which they live as developing little or not at all. Thus, they need to constantly (mis) translate culture and (re)negotiate positions and imaginaries. To avoid too much friction, tourism workers in developing countries must learn to position themselves in a transitional or liminal space that facilitates shifting between frames. One moment they are playing the immobile native (forced to be looking culturally inwards) and other moments they are distancing themselves from the locals (dreaming of roaming the wide world out there). This illustrates the complex entanglement of the politics of mobility and the politics of difference. The way in which (im)mobility in the context of transnational tourism is enacted and given meaning is intimately tied to widely circulating imaginaries of sameness and difference.

\section{CONCLUSION}

The in-depth study of tourism imaginaries-tracing their historical and semiotic makings, while keeping the very material effects of the processes in view-reveals that they are potent propellers of socio-cultural and environmental change, and essential elements in the process of identity formation, the making of place, and the perpetual invention of culture (K. M. Adams, 2004). We need to retain a clear idea about the chief interest groups behind these processes and avoid the mistake of seeing imaginaries as just a range of possibilities. Tourism imaginaries come to occupy a central position in a complex set of connections among very diverse societies, very dissimilar locales, and very different kinds of relations of production and consumption. They resonate most clearly in destinations, the physical and mental landscapes where the imaginaries of local residents, tourism intermediaries, and tourists meet and, occasionally, clash. As they are grounded in relations of power, they can never be politically neutral. The imagination in general is a pre-eminently world-shaping power (Brann, 1991). This power is "worldly" in a double sense: It makes imaginary worlds that do not exist and it invests the world that does with a second, imaginative surface (cf. Hollinshead, 2007).

Whatever the form of tourism indulged in, people always travel with a set of expectations derived from various sources (Skinner \& Theodossopoulos, 2011). Much of this prior information removes uncertainty and reduces risk on the one hand, yet on the other can also be seen as a form of control that channels tourist experiences into pre-determined forms. Tourism spaces, set apart from the mundane world for the tourists, are in part spaces of the imaginary, of fantasy, and dreaming. Places across the globe have different images attached to them. A series of social practices, ideologies, and behaviors derived from 
tourism imaginaries and their discourses subtly influence how people engage with the "Other" (cf. Tucker, 2009). I have focused mainly on western imaginaries of culture(s) in developing countries, but similar analyses can be made for non-western imaginaries (e.g. Wynn, 2007), for nature-related fantasies and their ecological consequences (e.g. Stepan, 2001), or for imaginaries about the western world by both westerners and others (Carrier, 1995).

The failure of both those studying tourism and those working in tourism to understand how imaginaries are embedded within local, national, regional, and global institutions of power restricts their ability to determine the underlying forces that restrict some tourism practices, and not others, some imaginings, and not others, and that make possible new hegemonies in new fields of power. Tourism imaginaries renegotiate political and social realities. The fierce local (and national) power struggle over globally circulating tourism imaginaries seeking to redefine peoples and places reaffirms that the social construction of place is still partly a process of local meaning-making, territorial specificity, juridical control and economic development, however complexly articulated localities become in transnational economic, political, and cultural movements. Even if many imaginaries have a distinctively Western genealogy, we have to be careful not to exaggerate their coherence and consistency and we need to acknowledge the agency and autonomy of those represented, because the imaginative flow has certainly not been a one-way street (Salazar, 2010). Besides, imaginaries are not only reworked in tourism (Kothari \& Wilkinson, 2010; Salazar, 2011).

To be more inclusive and to overcome Eurocentric tourism imaginaries, we need to move far beyond a language of ethnic minorities and colonized indigenous peoples (Winter, Teo, \& Chang, 2008). Non-Western players have long been actively collaborating in the often unruly circulation of tourism imaginaries. In order to arrive at a more nuanced account of tourism, attention needs to be focused on the relationships between the various elements and relations of tourism circuits, and the contradictions, anomalies, and paradoxes that these entail. In particular, attention should be paid to the ways in which values, meanings, and forms of knowledge can be altered, changed and renegotiated at all points, from prior expectations to the point of purchase and beyond, and the ways in which different forms of knowledge are (re)constructed or, as often is the case in tourism, do not change at all.

Tourism imaginaries often shrewdly exaggerate the power of difference while neglecting and obfuscating the power of commonality. Especially in developing countries, imaginaries shape frameworks for cultural interaction and influence against a broader background of cultural dissimilarity and the imaginative possibilities this creates (e.g. to build up cosmopolitan capital). While tourism is often characterized by exoticized holiday package products, moving beyond an imaginary, which is blind to whom the Other really is, is still a possibility that tourism offers for intercultural personal growth. To be a tourist, but also a tourism service provider, is to be mobile and transient and to become 
involved, even if only superficially, in the worlds and lives of others. While tourism often stands for the commoditization of a uni-dimensional culture, the exoticization and eroticization of contact with the Other, along with cosmopolitanisms constructed on the foundation of colonialism and orientalism, it can also foster interpersonal relationships which involve genuine intercultural exchanges. These opportunities are tourism's "imaginative horizons", the blurry boundaries that separate the here and now from what lies beyond, in time and space (Crapanzano, 2004). Such horizons profoundly influence both how all parties involved experience the tourism encounter and how they interpret this experience. Connections are made and unmade that reach beyond the specificity of time and place. It is a common story, one I have been told repeatedly (Salazar, 2010).

If we accept the possibility of tourism creating positive relations in a world hitherto unconnected, it becomes a key challenge to recognize and identify currently dominant tourism imaginaries, but also to actively create and operationalize new images and discourses that contest and replace tenacious imaginaries. This is a serious ethical imperative in which tourism scholars and educators obviously have a crucial role to play. This article offers but a critical introduction to a complex topic that is approached best in a multi-, cross-, inter- or, ideally, trans-disciplinary way. Finally, the subject of tourism imaginaries has so many practical implications that it offers unique opportunities to open up a constructive dialogue between tourism academics and practitioners. The free dissemination and open discussion of fine-grained empirical studies of the situated articulations and (dis)connections between tourism imaginaries and their broader context, for one, can also help people working in tourism to be much better prepared to recognize, identify and operationalize the imaginaries in which their business is so thoroughly embedded. A

Acknowledgements - This article is based on research supported by grants from the National Science Foundation (BCS-0514129 and BCS-0608991), the European Commission Directorate General Research (PIRG03-GA-2008-230892) and the Research Foundation-Flanders (1.2.210.09.N). Gadjah Mada University in Indonesia and the University of Dar es Salaam in Tanzania kindly acted as the local institutional sponsors, while the Indonesian Institute of Sciences (Permit No. 8093/SU/KS/2005) and the Tanzanian Commission for Science and Technology (Permit No. 2007-16-NA-2006-171) gave me the necessary research clearance. I am grateful to my research assistants, Erlis Saputra and Joseph Ole Sanguyan, for all their help. An earlier version of this paper was presented as keynote address at the Tourism Imaginaries/Imaginaires Touristiques International Conference at the University of California, Berkeley (February 18-20, 2011). I thank the organizers and the audience, as the anonymous reviewers of this journal, for their constructive comments and suggestions. All omissions and errors are mine alone.

\section{REFERENCES}

Adams, J. (2004). The imagination and social life. Qualitative Sociology, 27(3), 277-297.

Adams, K. M. (2004). The genesis of touristic imagery: Politics and poetics in the creation of a remote Indonesian island destination. Tourist Studies, 4(2), $115-135$. 
Amirou, R. (1995). Imaginaire touristique et sociabilités du voyage. Paris: Presses Universitaires de France.

Amirou, R. (2000). Imaginaire du tourisme culturel. Paris: Presses Universitaires de France.

Anderson, B. R. (1991). Imagined communities: Reflections on the origin and spread of nationalism (2nd ed.). New York: Verso.

Appadurai, A. (1996). Modernity at large: Cultural dimensions of globalization. Minneapolis: University of Minnesota Press.

Ateljevic, I. (2000). Circuits of tourism: Stepping beyond the 'production/ consumption' dichotomy. Tourism Geographies, 2(4), 358-369.

Ateljevic, I., Pritchard, A., \& Morgan, N. (Eds.). (2007). The critical turn in tourism studies: Innovative research methodologies. Amsterdam: Elsevier.

Bærenholdt, J. O., Haldrup, M., Larsen, J., \& Urry, J. (Eds.). (2004). Performing tourist places. Aldershot: Ashgate.

Bacchilega, C. (2007). Legendary Hawai'i and the politics of place. Tradition. translation, and tourism. Philadelphia: University of Pennsylvania Press.

Barthes, R. (1972). Mythologies (A. Lavers, Trans.). New York: Hill and Wang.

Bernstein, M., \& Studlar, G. (Eds.). (1997). Visions of the East: Orientalism in film. New Brunswick: Rutgers University Press.

Beaulieu, J., \& Roberts, M. (Eds.). (2002). Orientalism's interlocutors: Painting, architecture, photography. Durham: Duke University Press.

Bishop, R., \& Robinson, L. S. (1999). Genealogies of exotic desire: The Thai night market in the Western imagination. In P. A. Jackson \& N. M. Cook (Eds.), Genders and sexualities in modern Thailand (pp. 191-205). Chiang Mai: Silkworm.

Bissell, W. C. (2005). Engaging colonial nostalgia. Cultural Anthropology, 20(2), 215-248.

Brann, E. T. H. (1991). The world of the imagination: Sum and substance. Savage: Rowman \& Littlefield.

Carrier, J. G. (Ed.). (1995). Occidentalism: Images of the West. Oxford: Clarendon Press.

Bruner, E. M. (2005). Culture on tour: Ethnographies of travel. Chicago: University of Chicago Press.

Carter, S. (1998). Tourists' and travellers' social construction of Africa and Asia as risky locations. Tourism Management, 19(4), 349-358.

Castoriadis, C. (1987). The imaginary institution of society (K. Blamey, Trans.). Cambridge: MIT Press.

Clifford, J. (1997). Routes: Travel and translation in the late twentieth century. Cambridge: Harvard University Press.

Coleman, S., \& Crang, M. (Eds.). (2002). Tourism: Between place and performance. New York: Berghahn.

Crang, M. (2006). Circulation and emplacement: The hollowed out performance of tourism. In C. Minca \& T. Oakes (Eds.), Travels in paradox: Remapping tourism (pp. 47-64). Boulder: Rowman \& Littlefield.

Crapanzano, V. (2004). Imaginative horizons: An essay in literary-philosophical anthropology. Chicago: University of Chicago Press.

Crouch, D., Jackson, R., \& Thompson, F. (Eds.). (2005). The media and the tourist imagination: Converging cultures. London: Routledge.

Dann, G. M. S. (1976). The holiday was simply fantastic. Revue de Tourisme, 3, 19-23.

Dann, G. M. S. (1996). The language of tourism: A sociolinguistic perspective. Wallingford: CABI.

Du Gay, P., Hall, S., Janes, L., Mackay, H., \& Negus, K. (Eds.). (1997). Doing cultural studies: The story of the Sony Walkman. London: Sage.

d'Hauteserre, A.-M. (2011). Politics of imaging New Caledonia. Annals of Tourism Research, 38(2), 380-402.

Durand, G. (1999). The anthropological structures of the imaginary (M. Sankey \& J. Hatten, Trans.). Brisbane: Boombana Publications.

Echtner, C. M., \& Prasad, P. (2003). The context of Third World tourism marketing. Annals of Tourism Research, 30(3), 660-682.

Edensor, T. (1998). Tourists at the Taj: Performance and meaning at a symbolic site. London: Routledge. 
Edensor, T. (2001). Performing tourism, staging tourism: (Re)producing tourist space and practice. Tourist Studies, 1(1), 59-81.

Fabian, J. (2002). Time and the other: How anthropology makes its object (2nd ed.). New York: Columbia University Press.

Franklin, A. (2004). Tourism as an ordering: Towards a new ontology of tourism. Tourist Studies, 4(3), 277-301.

Gaonkar, D. P. (2002). Toward new imaginaries: An introduction. Public Culture, 14(1), 1-19.

Gold, J. R., \& Gold, M. M. (1995). Imagining Scotland: Tradition, representation, and promotion in Scottish tourism since 1750. Aldershot: Scolar Press.

Gregory, D. (1994). Geographical imaginations. Oxford: Basil Blackwell.

Hall, C. M., \& Tucker, H. (Eds.). (2004). Tourism and postcolonialism: Contested discourses, identities and representations. London: Routledge.

Harvey, D. (1989). The condition of postmodernity: An enquiry into the origins of cultural change. Oxford: Blackwell.

Henderson, C. E., \& Weisgrau, M. K. (Eds.). (2007). Raj rhapsodies: Tourism, heritage and the seduction of history. Aldershot: Ashgate.

Hennig, C. (2002). Tourism: Enacting modern myths (A. Brown, Trans.). In G. M. S. Dann (Ed.), The tourist as a metaphor of the social world (pp. 169-187). Wallingford: CABI.

Hollinshead, K. (1998a). Tourism and the restless people: A dialectical inspection of Bhabha's halfway populations. Tourism. Culture $\mathcal{E}$ Communication, 1(1), 49-78.

Hollinshead, K. (1998b). Tourism, hybridity, and ambiguity: The relevance of Bhabha's 'third space' cultures. Journal of Leisure Research, 30(1), 121-156.

Hollinshead, K. (2007). 'Worldmaking' and the transformation of place and culture. In I. Ateljevic, A. Pritchard, \& N. Morgan (Eds.), The critical turn in tourism studies: Innovative research methodologies (pp. 165-193). Amsterdam: Elsevier.

Hughes, G. (1992). Tourism and the geographical imagination. Leisure Studies, 11, $31-42$.

Hutnyk, J. (1996). The rumour of Calcutta: Tourism. charity, and the poverty of representation. London: Zed Books.

Imagineers (1996). Walt Disney imagineering: A behind the dreams look at making the magic real. New York: Hyperion.

Jenkins, O. H. (2003). Photography and travel brochures: The circle of representation. Tourism Geographies, 5(3), 305-328.

Johnson, S. (1963). [1759]). The Yale edition of the works of Samuel Johnson: The Idler and The Adventurer (Vol. 2). New Haven: Yale University Press.

Kearney, R. (1998). Poetics of imagining: Modern to post-modern (2nd ed.). New York: Fordham University Press.

Kirshenblatt-Gimblett, B. (1998). Destination culture: Tourism. museums, and heritage. Berkeley: University of California Press.

Kothari, U., \& Wilkinson, R. (2010). Colonial imaginaries and postcolonial transformations: Exiles, bases, beaches. Third World Quarterly, 31(8), $1395-1412$.

Kunz, H. (1946). Die anthropologische Bedeutung der Phantasie. Basel: Verlag für Recht und Gesellschaft.

Lacan, J. (1977). The mirror stage as formative of the function of the I (A. Sheridan, Trans.). In J. Lacan (Ed.), Ecrits: A selection (pp. 1-7). New York: W.W. Norton.

Law, J., \& Hassard, J. (Eds.). (1999). Actor network theory and after. Oxford: Blackwell.

Latour, B. (2005). Reassembling the social: An introduction to actor-network theory. Oxford: Oxford University Press.

Lewis, R. (2004). Rethinking orientalism: Women. travel, and the Ottoman harem. New Brunswick: Rutgers University Press.

Lowenthal, D. (1985). The past is a foreign country. Cambridge: Cambridge University Press.

Mercille, J. (2005). Media effects on image: The case of Tibet. Annals of Tourism Research, 32(4), 1039-1055. 
Morgan, N., \& Pritchard, A. (1998). Tourism promotion and power: Creating images. creating identities. Chichester: John Wiley.

Mowforth, M., \& Munt, I. (2008). Tourism and sustainability: Development, globalisation and new tourism in the Third World (3rd ed.). London: Routledge.

Narayan, K. (1993). How native is a "native" anthropologist?. American Anthropologist, 95(3), 671-686.

Picard, M. (1996). Bali: Cultural tourism and touristic culture. Singapore: Archipelago Press.

Pratt, M. L. (2008). Imperial eyes: Travel writing and transculturation (2nd ed.). London: Routledge.

Reijnders, S. (2011). Stalking the count: Dracula, fandom and tourism. Annals of Tourism Research, 38(1), 231-248.

Ricoeur, P. (1994). Imagination in discourse and in action. In G. Robinson \& J. F. Rundell (Eds.), Rethinking imagination: Culture and creativity (pp. 87-117). London: Routledge.

Robertson, R. (1990). After nostalgia? Wilful nostalgia and the phases of globalization. In B. S. Turner (Ed.), Theories of modernity and postmodernity (pp. 45-61). London: Sage.

Robinson, M., \& Andersen, H. C. (Eds.). (2002). Literature and tourism. London: Continuum.

Rosaldo, R. (1993). Culture and truth: The remaking of social analysis (2nd ed.). Boston: Beacon.

Roth, I. (2007). Imaginative minds. Oxford: Oxford University Press.

Said, E. W. (1994). Orientalism (Rev. ed.). New York: Vintage Books.

Selwyn, T. (Ed.). (1996). The tourist image: Myths and myth making in tourism. Chichester: John Wiley.

Salazar, N. B. (2005). Tourism and glocalization: "Local" tour guiding. Annals of Tourism Research, 32(3), 628-646.

Salazar, N. B. (2006). Touristifying Tanzania: Global discourse, local guides. Annals of Tourism Research, 33(3), 833-852.

Salazar, N. B. (2009). Imaged or imagined? Cultural representations and the "tourismification" of peoples and places. Cahiers d'Études Africaines, 49(193194), 49-71.

Salazar, N. B. (2010). Envisioning Eden: Mobilizing imaginaries in tourism and beyond. Oxford: Berghahn.

Salazar, N. B. (2011). The power of the imagination in transnational mobilities. Identities: Global Studies in Culture and Power, 18.

Sheller, M. (2004). Demobilizing and remobilizing Caribbean paradise. In M. Sheller \& J. Urry (Eds.), Tourism mobilities: Places to play, places in play (pp. 13-21). London: Routledge.

Skinner, J., \& Theodossopoulos, D. (Eds.). (2011). Great expectations: Imagination and anticipation in tourism. Oxford: Berghahn.

Stephen, A. (Ed.). (1999). Pirating the Pacific: Images of travel, trade $\mathcal{E}$ tourism. Aldershot: Ashgate.

Stepan, N. L. (2001). Picturing tropical nature. Ithaca: Cornell University Press.

Strauss, C. (2006). The imaginary. Anthropological Theory, 6(3), 322-344.

Sturma, M. (2002). South Sea maidens: Western fantasy and sexual politics in the South Pacific. Westport: Greenwood Press.

Taylor, C. (2004). Modern social imaginaries. Durham: Duke University Press.

Thomas, N. (1994). Colonialism's culture: Anthropology. travel, and government. Princeton: Princeton University Press.

Torgovnick, M. (1990). Gone primitive: Savage intellects. modern lives. Chicago: University of Chicago Press.

Tucker, H. (2009). Recognizing emotion and its postcolonial potentialities: Discomfort and shame in a tourism encounter in Turkey. Tourism Geographies, 11(4), 444-461.

Urbain, J.-D. (1994). L’idiot du voyage: Histoires de touristes. Paris: Éditions Payot \& Rivages.

Urban, G. (2001). Metaculture: How culture moves through the world. Minneapolis: University of Minnesota Press.

Urry, J., \& Larsen, J. (2011). The tourist gaze 3.0 (3rd ed.). London: Sage. 
van der Duim, R., Jóhannesson, G. T., \& Ren, C. (Eds.). (In Press). Actor Network Theory and tourism: Ontologies, methodologies and performances. London: Routledge.

Vogler, C. (2002). Social imaginary, ethics, and methodological individualism. Public Culture, 14(3), 625-627.

White, H. V. (1978). Tropics of discourse: Essays in cultural criticism. Baltimore: Johns Hopkins University Press.

Winter, T., Teo, P., \& Chang, T. C. (Eds.). (2008). Asia on tour: Exploring the rise of Asian tourism. London: Routledge.

Wynn, L. L. (2007). Pyramids and nightclubs: A travel ethnography of Arab and Western imaginations of Egypt. Austin: University of Texas Press.

Submitted 28 February 2011. Resubmitted 16 March 2011. Final version 9 October 2011. Accepted 14 October 2011. Refereed anonymously. Coordinating Editor: Hazel Tucker

Available online at www.sciencedirect.com

\section{SciVerse ScienceDirect}

